\title{
The Effect of Firm Cash Flow on Investment Decision Moderated by Financial Constraint and Mispricing
}

\author{
Andewi Rokhmawati* \\ Faculty of Economics and Bussines Universitas Riau, Pekanbaru, Indonesia \\ * andewi.rokhmawati@ lecturer.unri.ac.id
}

\begin{tabular}{|c|c|}
\hline Article Info & Abstract \\
\hline Received : 2019-05-28 & \multirow{4}{*}{$\begin{array}{l}\text { This study aims to examine the effect of cash flows on investment } \\
\text { decision that is moderated by financial constraint and mispricing. } \\
\text { The population of the study was all listed-manufacturing firms in } \\
\text { Indonesia from } 2014 \text { to } 2016 \text {. Samples were chosen based on the } \\
\text { available data of firms' audited-financial reports during the three } \\
\text { years. By using moderated regression analysis where financial } \\
\text { constraint and mispricing as moderating variables, the study } \\
\text { concluded that financial constraint weakens the effect of cash flow } \\
\text { on investment. Although lower financially constrained-firms have a } \\
\text { chance to decide their source of funding from any sources, they } \\
\text { prefer to funding their investment from an internal source of funding } \\
\text { (from cash flows) due to lower risk. Furthermore, mispricing does } \\
\text { not have a role as a moderating variable. In this condition, } \\
\text { overvalued firms are indifferent from choosing the source of } \\
\text { funding. Finally, when financial constraints and mispricing are } \\
\text { signed as moderating variables, they weaken the impact of cash flow } \\
\text { on investment. It means that firms with lower financial constraint } \\
\text { and overvaluation prefer to use external funding by issuing new } \\
\text { common stocks because it provides a lower cost of capital. }\end{array}$} \\
\hline Accepted : 2019-07-15 & \\
\hline Published : 2019-07-28 & \\
\hline $\begin{array}{l}\text { Key words: cash flows, financial } \\
\text { constraint, invesment decision }\end{array}$ & \\
\hline
\end{tabular}

\section{Introduction}

Investment decision is a central factor in a firm as firm's value can be maximized if the firm makes an investment. Many studies conducted in this area were based on the motivation of theoretical debates associated with the best models that can explain the behavior of investment.

According to Modigliani and Miller (1958), under perfect market conditions, there is no relationship between investment decisions and funding decisions. However, the assumption of perfect market conditions is not realistic so that there are many studies conducted to examine the association between investment decision and financing decisions under imperfect market conditions. To test whether financing decisions has relation with investment decision, many studies classified firms into two groups; financially constrained firms and financially unconstrained firms (see: Fazzari, Hubbard, and Petersen, 1988; Vogt, 1994; Kaplan and Zingales, 1997; Cleary, 1999; Moyen, 2004, Almeida, Campello, and Weisbach, 2004).

By measuring financial constraint as a dummy variable, the researchers compared the impact of internal source of funding measured as cash flow on investment between financiallyunconstrained firms and financially-constrained firms. The intensity of cash flow represents a financing decision that the funding is from the internal firm. There are two contrasting results of empirical tests in the effect of unconstrained-firms' cash flow on investment and the effect of constrained-firms' cash flow on investment that will be discussed further below.

The first group of research provided the result that financially-constrained firms have a higher sensitivity of cash flow-investment than financially-unconstrained firms. Fazzari et al 
The Effect of Firm Cash Flow on Investment Decision Moderated by Financial Constraint and Mispricing

(1988) defined financially-constrained firms as those who get an external source of funding with a very expensive cost so that the firms are only able to employ the internal source of funding (from cash flow) to finance their investment. Consequently, the firms are likely to distribute a low dividend payout ratio (DPR) to raise firms' retained earnings ratio. Fazzari et al (1988) identified that firms with lower DPR are classified as constrained firms and firms with higher DPR classified as unconstrained firms. Constrained firms have higher cash flow-investment sensitivity than unconstrained firms. Their result was supported by many other researchers such as Vogt (1994); Hovakimian and Hovakimian (2005); Hidayat (2010).

The second group such as Kaplan and Zingales (1997), Cleary (1999), Baker et al (2003), Kaaro (2004) gave a contrast result with the result of Fazzari at al (1988). They found that financially-unconstrained firms have a higher sensitivity of cash flow-investment than financiallyconstrained firms. Kaplan and Zingales (1997) characterized a firm as a high financing constraint when its external source of funding is more expensive than its internal source of funding such as bank loan, bond and share issuance. Insufficiency of internal funds and difficulty of obtaining bank loan makes this firm relies solely on the issuance of new shares to finance its investments (Baker et al., 2003). However, based on the Pecking order theory, the issuance of new shares usually becomes the last alternative to finance feasible opportunity of investments because issuing new shares has the most expensive cost of capital compared to other sources of funding (Kaaro, 2004). Hence, the high cost of capital from issuing new shares makes the feasible opportunity of investments even not feasible because its net present value (NPV) becomes negative. Thus, inevitably firms to access external funding makes them solely rely on cash flow generated from internal sources to funds that is cash flows from firm operation (Moyen, 2004). In other words, a company is called to be financially constrained if its costs of external funding far exceed its cost of internal funding (Kaplan and Zingales, 1997).

The mentioned studies above have been conducted and focused on the relationship between financial constraint, the sensitivity of cash flow-investment and investment decisions. They focus on how the availability of firms' internal cash flow has an impact on investment decisions by inserting variable financial constraints as a moderating variable. Whereas in relation to funding decisions from an external source of funding that is by issuing new shares may be closely related to the firm evaluation from the market. In evaluating a firm's value, investors are interested in the fundamental value of the firm and its market value. Based on fundamental and market value, a firm will be judged whether the firm is mispriced or not. When firm market value is higher than its fundamental value, the firm will be classified as an overvalued firm. In contrast, when firm's market value is lower than its fundamental value, the firm will be classified as an undervalued firm. By following the reasoning from logical thinking of market timing theory, Stein (1996) showed that firms will not finance their investment opportunities by issuing new shares if the firms' stock price is below its fundamental value (undervaluation). Instead, the company will issue new shares to fund investment opportunities if the market price of the stock is above its fundamental value (overvaluation). Thus, firms that have alternative sources of funding by issuing new shares should understand this mispricing phenomenon. Mispricing is an irregular and temporary condition in which the market price of a stock is not equal to its actual/fundamental price (Brennan and Ashley, 2010). Financial managers may take advantage of this condition in making decisions associated with a source of funding (Seifert and Gonenc, 2012). Mispricing may influence investment decisions in the following way. In a condition of market inefficiency, managers can take advantage of overvaluation by issuing new shares. A firm will benefit from the overvaluation of its firm because the firm's cost of capital from issuing new shares becomes cheaper (Chen et al., 2005). Market timing may provide firms a signal when they should issue new 
shares to finance their investment opportunities with a lower cost of capital (Dong et al., 2012). Market timing is believed to also be an important factor in investment decisions (Baker and Wurgler, 2002). Many studies examined the relationship between the mispricing and investment decision that was conducted by Polk and Sapianza (2004), Duong (2011), Brennan and Ashley (2010), and Wang, Zhao, and Wang (2013). They concluded that mispricing has a positive relationship with investment decisions.

Based on the explanation above, many studies have been done to examine the relationship between financial constraint, the sensitivity of cash flow-investment and investment decisions (Fazzari et al., 1988, Cleary, 2004, Alti 2006, Almeida et al., 2004, Kaplan and Zingales, 1997). Likewise, much research has been done to examine the relationship between mispricing, the sensitivity of cash flow-investment and investment decisions (Polk and Sapienza, 2004, Duong, 2011, Brennan and Ashley, 2010, Wang et al., 2013). Although there have been many empirical studies of these mentioned relationships, few studies have been conducted to examine the relationship by including the two variables: financial constraints and mispricing together in one research model. Besides financial constraints, mispricing is also an important phenomenon should be understood by managers to obtain a cheap source of funding, i.e. internal and external source of funding. This research gap will be filled by this study. The contribution of this study lies in how financial constraints and mispricing individually and jointly moderate the relationship between cash flow and investment. If this study can provide the expected relationship, this study may provide a suggestion for managers on when they should use an internal and external source of funding to finance their investment opportunity with a low cost of capital. This study also contributes to providing empirical evidence of the applicability of Pecking Order Theory and Market Timing Theory in the context of an emerging market like Indonesia Capital Market.

\section{Literature Review}

Using the reasoning of asymmetric information (Myers \& Majluf, 1984), Fazzari et al (1988) explored the connection between the cash flow-investment sensitivity, financing constraints, and investment decisions. Asymmetric information happens when the investors or creditors do not have the information about the firm conditions as much as the managers have (Ehrhardt and Brigham, 2014). The mangers hold detail and complete information on firm's risks and prospects. Meanwhile, investors and creditors do not have the information as much as the managers have. The asymmetry leads external funding to be very expensive because the owner of external funds (investors and creditors) have difficulty or even impossible to value the economic benefits and risks of the firm's investment opportunities. As a result, the owner will require a higher cost of debt and cost of equity, the more extensive of asymmetric information, the larger the constraint of firms to access external funding. Accordingly, the firm will extensively depend on the availability of internal-cash flow produced from its operation. Hence, the higher the financial constraint is the more sensitive the cash flow-investment of firms. Fazzari et al (1988) explained that firms experience a financial constraint when they have to pay much more costs to get external funding, so they do not have a choice to get external funding. The only source for funding of such firms is only from internal funding to finance investment. Consequently, the firms tend to pay a little dividend to improve their retained earnings. Furthermore, Fazzari et al (1988) classified firms with a low number of dividends as constrained firms and firms with a large amount of dividends as unconstrained firms. Financially-constrained firms have higher cash flow-investment sensitivity than unconstrained firms. Regardless of the weaknesses of their study that will be discussed further in this article, the study of Fazzari et al (1988) has made a significant contribution. The sensitivity of the cash flow-investment becomes one of the most important indicators used to measure financial constraints followed by many researchers. 
The Effect of Firm Cash Flow on Investment Decision Moderated by Financial Constraint and Mispricing

In contrast, Kaplan and Zingales (1997, 2000), Cleary (1999), Almeida et al (2004), and Bushman et al (2011) questioned the validity of the indicators used by Fazzari et al (1988). The literature points out that the approach to classifying the order of cash flow-investment sensitivity level greatly relies on how scholars measure the concept of financial constraint. The mentioned researchers spotted the limitation of Fazzari's et al (1988) work. Firstly, Fazarri et al (1988) classified firms into two groups that are financially-constraint firms and financially-unconstraint firms based on subjective perception, where the categorization is then used to develop an interpretation on the cash flow-investment sensitivity (Kaplan and Zingales, 1997, 2000). To improve the weakness of Fazzari's et al research, Kaplan and Zingales (1997, 2000) employed qualitative data gathering from interviewing firm managers and quantitative data of firm financial statements to categorize firms into a classification of financial-constraint level. Second, the second weakness is the measurement of investment opportunities by using Tobin q. Tobin's q is indicated to contain measurement errors because Tobin's q does not include cash flow in the calculations. It is more reliable if cash flow is included in the measurement of investment opportunity because such measurement is able to capture the phenomenon of firm financial constraint (see: Alti 2006, Poterba, 1988, Erickson and Whited, 2000, Gilchrist and Himmelberg, 1995). Third, Fazzari's et al (1988) model has a potential problem of misspecification. An important variable that is variable debt was not included in the model, whereas this variable has a significant correlation to the sensitivity of cash flow-investment. Firms that have debts must pay the interest and principal each month. Payments of interest and principal would reduce the availability of the firm's cash.

To improve the model Fazzari et al (1988), Kaplan and Zingales (1997, 2000) used qualitative data collected from interviewing firms' managers and quantitative data available in the firms' financial report to order firms based on firm-level of financial constraints. Kaplan and Zingales (1997) provided contrary evidence. Financially-unconstrained firms have easier access to external funding than financially-constrained firms. However, such firms rely more on internal funding to finance their investment. Kaplan and Zingales (1997) claimed that the firm's managers of unconstrained firms may avoid the risk to make their investment decision, so their investment rate becomes less sensitive to the availability of internal funds.

Another important concept of investment decision is mispricing. Baker and Wurgler (2002) stated that mispricing is the result of investor sentiment. They documented that a firm prefers to issue new stocks when its stocks are overvalued and buy back its stocks when undervalued. Mispricing is believed to influence on firm policy.

The theoretical model developed by Stein (1996) showed that firms whose high reliance on equity has higher mispricing. Firms that have a great dependency on their equity are characterized with holding low cash and having low debt capacity. Hence, to finance their investments, overvalued firms, which do not have enough internal sources of funds (cash flows), should issue new stocks. Conversely, undervalued firms tend to be reluctant to finance their feasible investment opportunity since issuing new stocks that are being undervalued will increase their cost of equity. The increase in the cost of equity leads to an increase in the cost of capital. The rise in the cost of capital will make investment opportunity become no longer feasible. The result of Stein's research was supported by Baker et al (2003) who examined the relationship between investment and mispricing by using multiple proxies for mispricing. Shleifer and Vishny (2003) also supported Stein's view (1996). Shleife and Vishny (2003) conducted a study on mergers and acquisitions. They concluded that overvaluation caused an increase in the level of the firm's investment.

Polk and Sapienza (2004) developed a theoretical model. In their model, they assume that market valuation on investment of new projects will depend on the present value of the project's expected cash flows. The result of the study showed that overvalued firms tend to over-invest. They tend to accept unfeasible projects where the projects have a negative net present value. In contrast, undervalued firms tend to under-invest; they tend to reject feasible projects where the projects have a positive net present value. 
Chirinko and Schaller (2001, 2004), Panageas (2003), and Gilchrist, et al (2005) also examined the association between mispricing and investment. They all concluded that mispricing influences investment. In particular, using data from the US, Gilchrist et al (2005) documented that positive sentiment of the market leads investors to value a stock with a higher price than its fundamental value. As a result, the firm tends to issue new stocks when the price is mispriced, specifically when the price is overvalued. This will lead the firm to increase its real investment. However, Chirinko and Schaller (2001) stated that the US market tends to be less volatile compared to other stock markets; as a result, the impact of bubbling investment was underestimated. Conversely, they gave evidence that mispricing has a strong impact on the firms' investment in Japan.

In order to control for a potential relationship between, financial constraints, mispricing, and the sensitivity of cash flow-investment, these variables are also included in the analysis: firm size, leverage, and sales.

\section{The Relationship between Financial Constraints, Mispricing and the Sensitivity of Cash Flow-Investment}

1. Kaplan and Zingales (1997) stated that the investment decisions of firms facing financial constraints related to the availability of cash flow in the firm to finance a firm's investment. Kaplan and Zingales (1997) said financial constraint could occur if a firm faces a considerable disparity between the cost of capital from internal funding and external funding. This definition provides a framework that is useful to distinguish companies between those who have a high level of financial constraints and those who have a low level of financial constraints. Firms with high financial constraints are characterized with the inadequately available cash flow and difficulty to obtain external funding. The limitation of firm ability to generate cash flow will eventually hamper the firm to invest. This can be concluded that firms with high financial constraints will have higher cash flow-investment sensitivity than firms with low financial constraints. In other words, financial constraints will weaken the sensitivity of the firms' cash flow-investment.

2. Mispricing is believed to affect investment decisions. Baker et al (2003) suggest that the company will benefit by issuing new stocks when a firm is overvalued. Thus, the market valuation on a firm's value becomes important to consider because when the price of the firm is overvalued. Firms can obtain funds by issuing new stocks at a lower cost to finance their investment. This is due to issue new stocks that are being overpriced will provide cheaper capital cost than the internal source of funding. Thus, the level of firm investment will much depend on an external source of funding. In other words, overpriced firms tend to be less dependent on internal cash flow to finance their investment. Hence, the investments of overvalued firms tend to be less sensitive to the availability of internal cash flow. This is because the capital cost of funds from issuing new stocks becomes cheaper. By contrast, the investment of undervalued firms tends to be more sensitive to the availability of internal cash flow. This is because issuing new stocks when the firm is undervalued will give a more expensive cost of capital to the firm.

Based on the developed argumentation, unconstrained firms have a larger ability to get funding from capital markets. When the firm is being overvalued, the firm may issue new stocks at a higher price than its actual price to finance its investments without difficulty. The issuance of new stocks at the high price will provide a firm with lower capital cost than the capital cost from its internal funding. Hence, the level of investment of less constrained firms may be more dependent on external funding. This may occur if the cost of capital from external funding is cheaper than the cost of its internal funding. In other words, when the firm is being overpriced the investment level of a less-constrained firm may be less sensitive to the availability of internal cash flows. Therefore, a less-constrained firm is more flexible to adjust its investment policy to respond to the mispricing. Less-constrained firms can switch between external and internal funding, 
The Effect of Firm Cash Flow on Investment Decision Moderated by Financial Constraint and Mispricing

whichever gives a lower cost of capital. A research model for the relationship between financial constraints, mispricing and the sensitivity of cash flow-investment can be seen as follows:

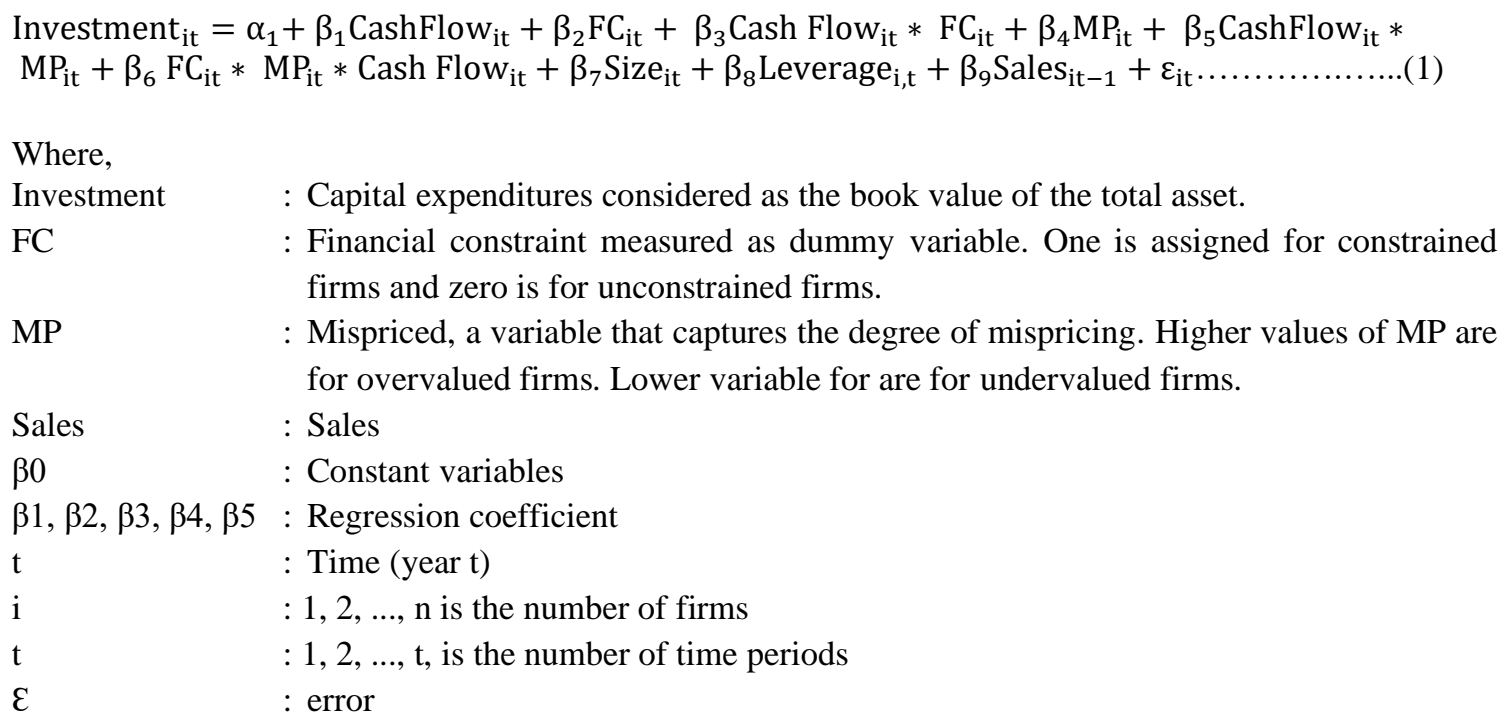

Based on the explanation above, some hypothesis can be proposed as follows:

Ha: $\quad \beta 1>0$; cash flow of less-constrained firm with zero mispricing has a positive and significant impact on investment

$\mathrm{Hb}: \quad \beta 3<0$; financial constraint weakens the effect of cash flow on investment

Hc: $\quad \beta 5<0 ;$ mispricing weakens the effect of cash flow on investment

Hd: $\quad \quad \quad \beta 6>0$; financial constraint and mispricing are able to strengthen the effect of cash flow on investment.

\section{Classical Assumption Tests}

To conduct a regression analysis with ordinary least square (OLS), there are some classical tests should be done to test the classical assumptions underlying the OLS regression analysis so that the model is reliable. The tests consist of the normality test of the residual of the regression, multicollinearity, heteroscedasticity, and autocorrelation (Ghozali, 2011). However, multicollinearity is not required for the regression model with moderating variables. This is because the moderating variable is the result of an interaction between one independent variable and other independent variables (Ghozali, 2011).

\section{Sample Selection and Variable Definitions}

Samples of this research were manufacturing firms that are listed in the Indonesian Stock Exchange (IDX) which published their financial statements covering the period of this research from the year 2014 up to 2016. All data used in this study can be gotten from the Indonesian Capital Market Directory (ICMD) or the websites www.idx.co.id. The data are secondary data that are available from the firms' financial statements. To select the samples, this study used purposive sampling in which only firms that provide complete financial reports from 2014 to 2016.

\section{Investment Decision}

Generally, investment decisions include investment in short-term assets (current assets) and fixed assets. Short-term assets usually defined as assets with a maturity of less than one year or less than one business cycle. Firms' investment in short-term assets is used as working capital. Fixed assets 
are defined as assets with maturities more than one year. In terms of investment in fixed assets, the firms will receive back their investment in the long run usually more than one year and the firm will receive the repayment progressively. Firms' goal to invest in fixed assets is to increase the value of a firm (Hidayat, 2010). In this research, investment decisions are measured with the following formula (Chang, et al., 2009):

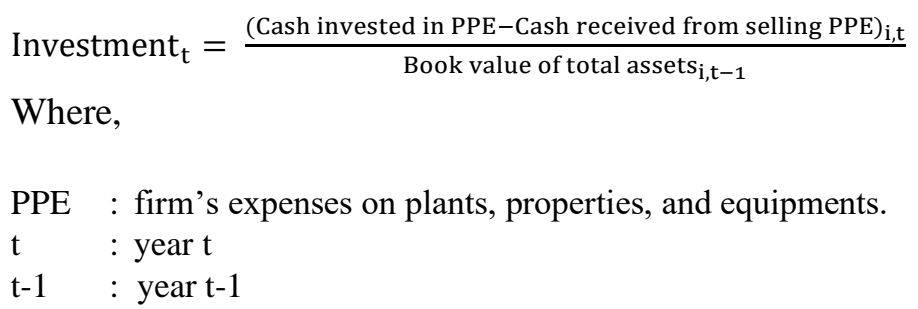

\section{Cash Flows}

Firms which have financial constraint will have difficulties to get funding from capital markets so that such firms will greatly depend on the availability of internal funds (cash flow from firm operating activities) to finance their investment opportunities. Hence, only firms that have a large cash flow are able to finance their investments. Cash flow was measured with the following formula (Chang et al., 2007) and Kaplan and Zingales (1997):

CashFlow $_{\mathrm{i}, \mathrm{t}}=\frac{[\text { Net income }+ \text { Depreciation dan amortization }]_{\mathrm{i}, \mathrm{t}}}{\text { Book value of total assets }}$

\section{Financial Constraints}

The degree of financial constraints faced by a firm highly relies on the extent to which the cost of capital from external funding is different from internal funding. This study adopts the approach of classifying used by Kaaro (2004) to assign samples into either financially-constraint firms or financially-unconstraint firms. The first classification of financially constraint firms or financially unconstraint firms is based on firms' dividend policy. Firms that pay a dividend are included in the category of unconstrained firms; while firms that do not pay dividend included as constrained firms. Furthermore, to predict whether firms will face financial constraint or not in the future this study uses some relevant financial variables to predict the level of dividend. This study employs a logit model to obtain the predictive categorization of constrained and unconstrained firms by considering that the logit model does not need to conduct classical tests (Eisenbeis, 1997). Financial variables used to refer to variables that were used by Kaplan and Zingales (1997) and Cleary (1999), Kaaro (2004), Rinofah (2011), and Rokhmawati (2017), namely:

1. Liquidity measured with current ratio is considered before firms decide to pay a dividend.

2. Profitability measured the ability of firms to pay dividends. Profitability in this study is defined as the ratio of earnings before interest and tax (EBIT) divided by total assets.

3. Change in profit is measured as a dummy variable. Firms that have a positive change in profit will be assigned a score one and zero is otherwise.

4. Retained earnings measured the accessibility of cash that can be used to pay dividends.

5. Slack is considered as the ease of use of funds to finance investment or other purposes (paying dividends and others).

6. Financial constraint is measured as a dummy variable. Financially constrained firms that do not pay a dividend will be given a score one and zero is otherwise. 
The Effect of Firm Cash Flow on Investment Decision Moderated by Financial Constraint and Mispricing

To measure the degree of financial constraint, here are the steps.

1. Developing a logit model to get the prediction of financial constraint as follows:

$\mathrm{P}_{\mathrm{i}}=\frac{1}{1+\mathrm{e}^{-\mathrm{z}}}=\frac{\mathrm{e}^{\mathrm{z}}}{1+\mathrm{e}^{\mathrm{z}}}$

$\mathrm{Z}_{\mathrm{i}, \mathrm{t}}=\alpha_{0}+\beta_{1} \mathrm{FP}_{\mathrm{i}, \mathrm{t}}$

$\mathrm{FP}_{\mathrm{i}}=\operatorname{Ln}\left(\frac{\mathrm{P}_{\mathrm{i}}}{1-\mathrm{P}_{\mathrm{i}}}\right)=\alpha_{0}+\beta_{1} \mathrm{CR}+\beta_{2}$ PROFIT $+\beta_{3} \mathrm{EC}+\beta_{4}$ SLACK $+\beta_{5} \mathrm{RE}+\varepsilon_{\mathrm{i}, \mathrm{t}}$

Where

$\mathrm{FP}_{\mathrm{i}} \quad$ : Financial constraint of firm $\mathrm{i}$

PROFIT

: Current ratio measured as total current assets divided by total current liabilities

: Measured as operating income divided by total assets

EC (EAT Change) : Earning After-Tax change. Positive changes will be scored one; negative change will be scored zero.

SLACK

: Cash+short term investment+inventories+receivable-current liablilities

RE (retained earnings): $\frac{\text { Retained Earnings }}{\text { Total assets }}$

$\mathrm{P}_{\mathrm{i}} \quad$ : Probability

e : exponential value

2. The estimation results of $\alpha, \beta 1, \beta 2, \beta 3, \beta 4$, and $\beta 5$ of the logit model then are used to calculate the probability of the financial constraint in equation 6 which is used to compute the cut-off $\left(\mathrm{C}^{*}\right)$ value to distinguish between financial constraint and financial unconstraint. If the firm's FPi is greater than the cut off (FPi $>\mathrm{C}^{*}$ ), the firm is classified as a financially-constrained firm. Conversely, if FPi $<\mathrm{C}^{*}$, the firm is classified as a financially-unconstrained firm.

3. Determining the $\mathrm{C}^{*}$ by following the value of the percentile at $67.78 \%$. Firms with FPi greater than $\mathrm{C}^{*}$ are categorized as a financially-constrained firm vice versa

4. Dummy variable of financial constraints. Firms classified as financially constrained are assigned score one, zero for otherwise.

\section{Mispricing}

In this study, mispricing is measured with discretionary accruals (Polk and Sapienza, 2004, Teoh et al., 2004, Chang et al., 2012). Current accruals (ACCR) are the discrepancy between accounting earnings and their underlying cash flows. Accruals are broken into two parts: discretionary and non-discretionary. Discretionary accruals (DACCR) are an unusual part of the accrual opened for managerial manipulation. Meanwhile, non-discretionary accruals (NDACCR) are part of the accrual measuring normal business conditions of the firm. Initial Public Offering (IPO) firms with high discretionary accruals tend to have lower returns than companies with lower discretionary accruals. This indicates that the firm's enterprise with discretionary accruals (DACCR) was likely overvalued. Current accrual can be calculated with the following formula Chang et al (2007):

$\mathrm{ACCR}_{\mathrm{i}, \mathrm{t}}=\Delta \mathrm{NCCA}_{\mathrm{i}, \mathrm{t}}-\Delta \mathrm{CL}_{\mathrm{i}, \mathrm{t}}-\mathrm{DEPN}_{\mathrm{i}, \mathrm{t}}$

Where:

NCCA : non-cash current assets; 
CL $\quad$ : current liabilities;

DEBT : debt

DEPN : depreciation and amortization.

The following equation can be used to compute non- discretionary accruals (NDACCR) (Chang et al, 2007):

$\frac{\mathrm{ACCR}_{\mathrm{j}, \mathrm{t}}}{\mathrm{A}_{\mathrm{j}, \mathrm{t}-1}}=\beta_{0} \frac{1}{\mathrm{~A}_{\mathrm{j}, \mathrm{t}-1}}+\beta_{1} \frac{\Delta \text { SALES }_{\mathrm{j}, \mathrm{t}}}{\mathrm{A}_{\mathrm{j}, \mathrm{t}-1}}+\beta_{2} \frac{\mathrm{PPE}_{\mathrm{j}, \mathrm{t}}}{\mathrm{A}_{\mathrm{j}, \mathrm{t}-1}}+\mu_{\mathrm{j}, \mathrm{t}}$

Where,

$\mathrm{A}_{\mathrm{jt}-1} \quad$ : Total assets for firm $\mathrm{j}$ at time $\mathrm{t}-1$;

$\triangle$ SALES $_{\mathrm{jt}}$ : Sales of firm $\mathrm{j}$ at time $\mathrm{t}-$ sales of firm $\mathrm{j}$ at time $\mathrm{t}-1$.

$\mathrm{PPE}_{\mathrm{jt}} \quad$ : plant, property and equipment of firm $\mathrm{j}$ at time $\mathrm{t}$.

Non-discretionary accruals (NDACCR ${ }_{\mathrm{it}}$ ) of considered firms can be calculated by using coefficient estimation as follows:

$\operatorname{NDACCR}_{i, t}=\beta_{0} \frac{1}{A_{i, t-1}}+\beta_{1} \frac{\Delta \operatorname{SALES}_{i, t}-\Delta \mathrm{AR}_{i, \mathrm{t}}}{A_{i, t-1}}+\beta_{2} \frac{\operatorname{PPE}_{i, \mathrm{t}}}{\mathrm{A}_{\mathrm{i}, \mathrm{t}-1}}$

Where:

$\triangle \mathrm{AR}_{\mathrm{it}}$ is defined as a change in receivable account. Then, discretionary accruals $\left(\mathrm{DACCR} \mathrm{it}_{\mathrm{it}}\right)$ can be calculated as follows:

$\operatorname{DACCR}_{i, t}=\frac{\text { ACCR }_{i, t}}{A_{i, t-1}}-$ NDACCR $_{i, t}$

\section{Variable Control}

This research employed three control variables: leverage, size, and sales that the measurement of each variable can be seen as follows:

Leverage measured by the following formula (Aivazian, et al., 2005):

Leverage $_{\mathrm{i}, \mathrm{t}-1}=\frac{\left[\text { short term liabilities } \mathrm{i}_{\mathrm{i}-\mathrm{t}-1}+\text { long term debt }\right.}{\mathrm{i}, \mathrm{t}-1]}$.

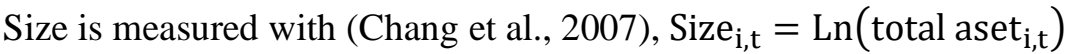

Sales are measured in Ln sales $($ Chang et al., 007)

\section{Results and Analysis}

The regression model was developed to look at the effect of cash flow on investment moderated by financial constraints and mispricing. Based on the statistical results in Table 1 , the regression model can be seen as follows:

Investment $_{i t}=0.067+0.076$ CashFlow $_{i t}+0.013 \mathrm{FC}_{\mathrm{it}}-0.098$ CashFlow $_{i t} *$

$\mathrm{FC}_{\text {it }}+0.243 \mathrm{MP}_{i t}-1.589$ CashFlow $_{\text {it }} * \mathrm{MP}_{\mathrm{it}}+14.091 \mathrm{FC}_{\mathrm{it}} * \mathrm{MP}_{\mathrm{it}} *$ CashFlow $_{\mathrm{it}}+$ 
The Effect of Firm Cash Flow on Investment Decision Moderated by Financial Constraint and Mispricing

$$
\begin{aligned}
& 0.004 \text { LnSize }_{i t}-0.046 \text { Leverage }_{i, t-1}+ \\
& 0.003 \text { LnSales }_{\text {it }-1}
\end{aligned}
$$

Statistic results of regression model are presented in Table 1.

Table 1. Statistic Results of Regression Model

Model Summary

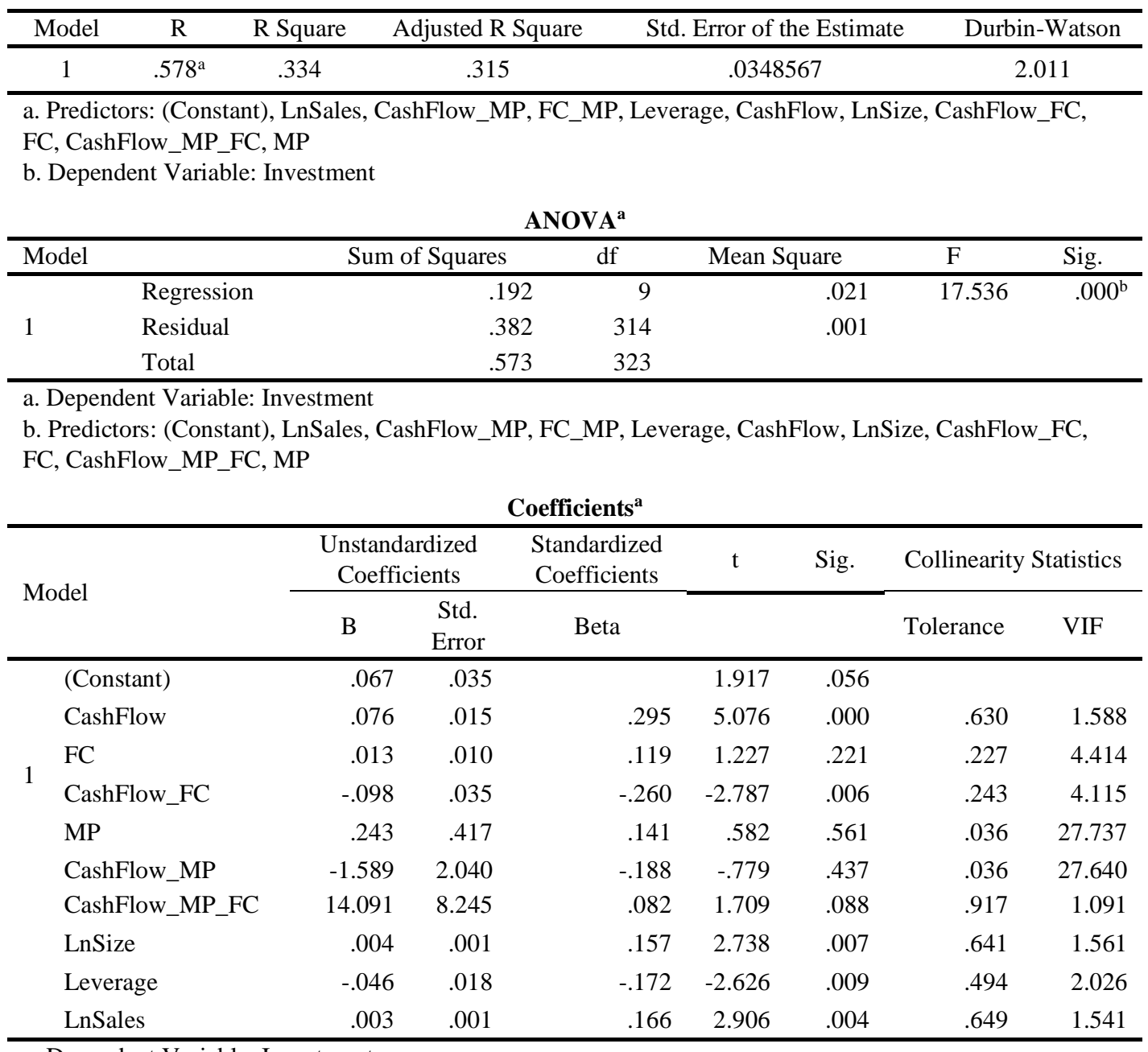

a. Dependent Variable: Investment

Source: calculated data

At a confidence level of $95 \%$, the $\mathrm{F}$ test has a significance value of 0.000 where the value of $\alpha$ is less than 0.05 . This means that jointly independent variables have a significant effect on investment. The result of the $\mathrm{R} 2$ is $33.4 \%$, which means that variables included in the model can explain the dependent variable at $33.4 \%$. The rest of it is explained by other variables not included in the model.

Furthermore, based on the t-test each parameter can be seen that $\beta 1$ showed positive results (0.076) and significant. This result means that unconstrained firms with zero-mispricing have $\beta$ equal to 0.076 means that every one percent increase in the cash flow will increase its investment by 0.076 percent.

The value of $\beta 3$ represents the difference in cash flow-investment sensitivity between unconstrained firms and constrained firms with zero-mispricing, is equal to -0.098 . Thus, the 
sensitivity of cash flow-investment for constrained firms with zero-mispricing is equal to -0.22 based on the calculation of $0.076+(-0.098)$. This means that unconstrained firms with zeromispricing have higher $\beta(0.076)$ than constrained firms with zero-mispricing have $(-0.22)$. The negative sign on the value of $\beta 3$ indicates that the variable financial constraint significantly weakens the effect of cash flow on investment. This means that unconstrained firms with zeromispricing are more sensitive than firms with financial constraints and with zero-mispricing. It can be restarted with a different sentence that firms with financial constraints and with zeromispricing are less sensitive than firms with financial unconstraint and with zero-mispricing. This result implies that unconstrained firms tend to finance their investments from internal sources of funding. This result contrasts with the results of Fazzari et al (1988) but the result is consistent with the findings documented by Kaplan and Zingales (1997) and Cleary (1999). Although unconstrained firms with zero-mispricing have more access to use external funding from debt with low cost of capital, these firms are seen more preferred to use a source of capital from internal cash flow. This may be because the utilization of the internal source of funding provided lower risk since debt usage to finance firm investment will increase risk. The increase in debt level will even worsen the availability of cash flow because firms must pay higher interest. This result strengthens by the negative effect of leverage on investment. It means that the increase in debt will reduce firm investment.

The sensitivity of flow-investment $(\beta 5)$ represents a change in the sensitivity of cash flowinvestment for each unit change in mispricing where the beta is -0.1589 . Based on the result, it can be calculated that the coefficient beta or sensitivity of cash flow-investment unconstrained firms with mispricing is amounted at -0.1513 based on the calculation of $0.076+(-1.589)$. These figures imply that unconstrained firms with zero-mispricing have a higher beta (0.076) than unconstrained firms with mispricing $(-0.1513)$. $\beta 5$ has a negative sign that the negative sign implies that mispricing weakens the effect of cash flow on investment but the effect is not significant with sig value at 0.437 . In other words, the higher mispricing/overvaluation the lower firms rely on the internal source of funding. It can be stated that the higher mispricing/overvaluation the firms tend to rely on an external source of funding. Overvalued firms prefer to use an external source of funding by issuing new shares. Issuing new stocks when the firm is being overvalued may provide a cheaper cost of capital. However, this effect exhibited not significant.

$\beta 6$ represents the financial flexibility of firms to respond mispricing. $\beta 6$ has value 14.091 indicating that the intersection of financial constraints and mispricing strengthen the effect of cash flow on investment, significant at a 90 percent confidence level. Essentially, the result indicates that constrained firms with overpricing are more sensitive than unconstrained firms with overpricing. It is known that constrained firms are hampered to access funds from external sources; this situation makes constrained firms difficult to issue new shares, even if a company is in overvalued so that such firms tend to rely on the availability of internal cash flow than similar firms that are not facing financial constraint. In other words, constrained firms are less flexible to adjust their financial resource of funding to finance their investment to respond to the condition of overpricing. The reversal condition might be experienced by unconstrained firms in which they have greater access to capital markets. Such firms are more flexible in adjusting their sources of funding. Under conditions of overvaluation, unconstrained firms have the ability to finance their investments from issuing external funding without difficulty. Thus, unconstrained firms tend to be more flexible to adjust their source of funding between an internal and external source of funding to finance their investment to respond to overpricing, which one provides a lower cost of capital. 
The Effect of Firm Cash Flow on Investment Decision Moderated by Financial Constraint and Mispricing

\section{Conclusion}

From the value of beta and the significant value from the statistic results, the study concluded that firstly, the cash flow of unconstrained firms with zero-mispricing has a significant effect on investment. Secondly, the value of $\beta 3$ shows that variable financial constraint significantly weakens the effect of cash flow on investment. It means that unconstrained firms with zeromispricing have higher beta than constrained firms with zero-mispricing. It means that unconstrained firms with zero-mispricing tend to use an internal source of funding. Thirdly, $\beta 5$ shows that variable mispricing weakens the effect of cash flow on investment. It means that unconstrained firms with zero-mispricing have higher cash flow-investment sensitivity than unconstrained firms with mispricing but the effect is not significant. It means that unconstrained firms with overpricing tend to less depend on the internal source of funding to finance their investment. In other words, unconstrained firms with overpricing tend to depend on external funding by issuing new shares. The insignificant result might be because when overpricing, unconstrained firms may not be interested to issue new shares because the owners of the firms want to keep their dominant control in voting right. Fourthly, $\beta 6$ shows that the intersection between financial constraint and mispricing significantly strengthens the effect of cash flow on investment.

Unconstrained firms with overpricing are much flexible to adjust their source of funds between internal funding and external funding to finance their investment. In this condition, unconstrained firms tend to prefer the use of funding from external funding sources because the overvalued condition of external funding provides a cheaper cost of capital. Furthermore, constrained firms with overpricing are less flexible to adjust their source of funds between internal funding and external funding.

The results of this study have some contributions for practice, for theory, and for future research. For practice, it is recommended that firstly, when firms are under the condition of unconstrained with zero-mispricing, firms with sufficient cash holding should use their internal cash flow to finance their investment rather than using debt. This recommendation has an implication for firms that firms should distribute a low DPR. Secondly, when firms are under the condition of unconstrained and overvalued, it is recommended that firms can issue new stocks to finance their investment. This recommendation has an implication for firms that firms should distribute a high DPR.

This research has a contribution to theory. It is known that pecking order theory orders the source of funding from the cheapest to the most expensive. They are retained earnings, bank loans, bonds, preferred stocks, and common stocks. This order is not always ordered from retained earnings from internal cash flow to common stocks. This order is not perfectly applicable. In the condition where firms experience overvaluation and financially unconstraint they can use a source of funding even from issuing common stocks that according to pecking order theory issuing common stocks becomes the last source of funding.

Finally, the results of this study also have implications for future research. Although the direction of coefficient mispricing performed as expected, the variable mispricing is not significant to moderate the effect of cash flow on investment. This raises a question that perhaps discretionary accruals as a proxy of mispricing is not reliable enough. For future research, mispricing may be measured with Composite Share Issuance (CSI) developed by Daniel and Titman (2006) and Polk and Sapienza (2004).

\section{References}

Almeida, H., M, Campello., \& Weisbach, M. (2004). The Cash Flow Sensitivity Of Cash. Journal Of Finance, 59, 1777-1804.

Alti, A. (2006). How Persistent In The Impact Of Market Timing On Capital Structure. Journal Of Finance, 61, 1681-1710. 
Aviazian, et al. (2005). The Impact Of Leverage On Firm Investment: Canadian Evidence Journal Of Corporate Finance, 11, 277-291.

Baker, M., Stein, J. C., \& Wurgler, J. (2003). When Does The Market Matter? Stock Prices And The Investment Of Equity-Dependent Firms. Quarterly Journal Of Economics, 118, 9691004.

Baker, M., \& Wurgler, J. (2002). Market Timing And Capital Structure. Journal Of Finance, 57, $1-32$.

Brennan, M. J., \& Ashley, W. (2010). The Mispricing Return Premium. The Review Of Financial Study, 23, 4437-3473.

Bushman, R. M., Smith, A. J., \& Zhang, F. (2011). Investment-Cashflow Sensitivities Are Really Investment-Investment Sensitivities. Working Paper.

Chang, X., Faff, R. W., Kwok, W. C., \& Wong, G. (2009). Financial Constraints, Mispricing And Corporate Investment. March 12, 2009 Ed.

Chang, X., Lewis, H. K., Tam, T. J., \& Tan, G. W. (2007). The Real Impact Of Stock Market Mispricing - Evidence From Australia. Pacific-Basin Finance Journal.

Chen, Q., Goldstein, I., \& Jiang, W. (2005). Price Informativeness And Investment Sensitivity To Stock Price. The 14th Annual Conference On Financial Economics And Accounting Indiana University.

Cleary, S. (1999). The Relationship Between Firm Investment And Financial Status. Journal Of Finance, 54, 673-692.

Cleary, S. (2004). International Corporate Investment And Role Of Financial Constraints. Working Paper. Toronto: York University.

Dong, M., Loncarski, I., Ter-Horst, J., \& Veld, C. (2012). What Drives Security Issuance Decisions: Market Timing, Pecking Order, Or Both? Financial Management, 41, 637-663.

Duong, C. M. (2011). Revisiting The Effect Of Market Mispricing On Corporate Investment: A Decomposition Of Q. Centerbury: University Of Centerbury.

Ehrhardt, M. C., \& Brigham, E. F. (2014). Corporate Finance: A Focused Approach, Ohio, Cengage Learning.

Erickson, T., \& Whited, T. (2000). Measurement Error And The Relationship Between Investment And Q. Journal Of Political Economy 108, 1027-1057.

Fazzari, S. M., Hubbard, R. G., \& Petersen, B. C. (1988). Financing Constraints And Corporate Investment. Brookings Paper On Economic Activity, 1, 141-206.

Ghozali, I. (2011). Aplikasi Analsis Multivariate Dengan Program Spss19, .

Semarang, Badan Penerbit Univ. Diponegoro.

Gilchrist, S., \& Himmelberg, C. P. (1995). Evidence On The Role Of Cash Flow In Reducedform Investment Equations. Journal Of Monetary Economics, 36, 541-572.

Hadlock, C., \& Pierce, J. (2010). New Evidence On Measuring Financial Constraints: Moving Beyond The Kz Index. Review Of Financial Studies, 23, 1909-1940. 
The Effect of Firm Cash Flow on Investment Decision Moderated by Financial Constraint and Mispricing

Hidayat, R. (2010). Keputusan Investasi Dan Financial Constraint: Study Empiris Pada Bursa Efek Indonesia. Buletin Ekonomi Moneter Dan Perbankang, 458-479.

Kaaro, H. (2004). Informasi Asimetri Dan Kontrol Manajemen: Analisis Kepekaan Investasi Dan Leverage Terhadap Pemilihan Sumber-Sumber Pendanaan. Doktor, Universitas Gadjah Mada.

Kaplan, S. N., \& Zingales, L. (1997). Do Investment-Cash Flow Sensitivities Provide Useful Measures Of Financing Constraints? Quarterly Journal Of Economics, 112, 169-215.

Kaplan, S. N., \& Zingales, L. (2000). Investment-Cash Flow Sensitivities Are Not Valid Measures Of Financing Constraints. The Quarterly Journal Of Economics, 115, 707-712.

Moyen, N. (2004). Investment-Cash Flow Sensitivities: Constrained Versus Unconstrained Firms. Journal Of Finance, 59, 2061-2092.

Myers, S., \& Majluf, N. (1984). Corporate Financing And Investment Decisions When Firms Have Information That Investors Do Not Have. Journal Of Financial Economics, 13.

Polk, C., \& Sapienza, P. (2004). The Real Effects Of Investor Sentiment. Working Paper.

Poterba, J. M. (1988). Comment On 'Financial Constraints And Corporate Investment'. Brookings Paper On Economic Activity, 1, 200-204.

Seifert, B., \& Gonenc, H. (2012). Issuing And Repurchasing: Mispricing, Corporate Livecycle Or Financing Waves. Journal Of Multinational Financial Management.

Stein, J. C. (1996). Rational Capital Budgeting In An Irrational World. Journal Of Business, 69, 429-455.

Teoh, S. H., Welch, I., \& Wong, T. J. (2004). Earnings Management And The Long-Run Market Performance Of Initial Public Offerings. Journal Of Finance, 53, 1935-1974.

Wang, S.-S., Zhao, F., \& Wang, D.-F. (2013). The Effect Of Stock Market Mispricing On Investment -Evidence From China. Wseas Transactions On Systems, 12, 593-603.

Watson, D., \& Head, A. (2013). Corporate Finance: Principles And Practice London, Prentice Hall. 